\title{
EVALUASI PENERAPAN STANDAR AKREDITASI PENJAMINAN MUTU PENGADILAN DENGAN IMPORTANCE PERFORMANCE ANALYSIS
}

\author{
Evaluation the Implementation of Court Quality Accreditation Standard Using \\ Importance Performance Analysis
}

\author{
Zulfia Hanum Alfi Syahr \\ Pusat Penelitian dan Pengembangan Hukum dan Peradilan Mahkamah Agung Republik Indonesia \\ Jl. Jend. Ahmad Yani Kav. 58 bypass, Cempaka Putih, Jakarta Pusat, Indonesia \\ e-mail: qvia.alfisyahr@gmail.com
}

Diterima: 18 Desember 2018, Direvisi: 11 Februari 2019, Disetujui: 8 Maret 2019

\begin{abstract}
Abstrak
Mahkamah Agung RI sebagai lembaga peradilan yang membawahi empat lingkungan peradilan, memilki tanggung jawab untuk menjamin pengadilan-pengadilan dibawahinya memberikan layanan keadilan yang optimal kepada masyarakat. Hal tersebut tercermin dalam SK KMA Nomor: 026/KMA/SK/II/2012 tentang Standar Pelayanan Peradilan. Kebijakan ini disikapi oleh Badan Peradilan Umum (Badilum) dengan dibuatnya program Akreditasi Penjaminan Mutu (APM) untuk lingkungan peradilan umum tingkat banding maupun tingkat pertama. Program tersebut telah menghasilkan akreditasi bagi hampir semua pengadilan tingkat banding dan tingkat pertama di seluruh Indonesia. Upaya peningkatan pelayanan lembaga peradilan kepada masyarakat dilakukan dengan evaluasi terhadap program APM yang telah berjalan. Evaluasi tersebut dimaksudkan untuk mengetahui apakah kinerja yang telah terstandar tersebut telah mampu memenuhi harapan masyarakat sebagai pengguna layanan peradilan. Penelitian ini membahas tentang hal-hal apa saja yang memerlukan perbaikan ataupun peningkatan pada beberapa kriteria akreditasi yang menjadi prioritas masyarakat. Hasil tersebut dapat dijadikan sebagai masukan dan pertimbangan stakeholders di lingkungan peradilan umum maupun di Mahkamah Agung RI dalam mengambil kebijakan. Metode yang digunakan adalah deskriptif kuantitatif dengan menggunakan analisis matriks Importance Performance Analysis (IPA). Matriks IPA diperoleh dari nilai-nilai yang menjadi indikator pada kriteria APM dan kepuasan masyarakat. Hasil yang diperoleh dari analisis tersebut adalah matriks perbandingan kinerja nyata yang telah diberikan pengadilan terhadap kepuasan masyarakat yang dicapai. Hasil evaluasi matriks IPA menunjukkan indikator dari masing-masing kriteria APM masih banyak yang perlu ditinjau kembali oleh stakeholder untuk dapat dilakukan perbaikan dan peningkatan pada beberapa kriteria akreditasi yang menjadi prioritas masyarakat. Kriteria akreditasi yang telah memenuhi harapan masyarakat adalah fokus pelanggan dan manajemen sumber daya. Kriteria akreditasi lainnya yang belum memenuhi harapan masyarakat adalah manajemen proses.
\end{abstract}

Kata kunci: akreditasi, IPA, mutu layanan, pengadilan

\begin{abstract}
The Supreme Court of Indonesia as a judiciary that oversees four judicial environments, has the responsibility to ensure that the courts which underlie provide optimal justice services to the public. This is reflected in the KMA Decree Number: 026 / KMA / SK / II / 2012 concerning Judicial Service Standards. The policy was addressed by the General Judiciary (Badilum) with the establishment of an Quality Assurance Accreditation Program (APM) for the appellate and first-level general justice. The APM program resulted in the accreditation of almost all the appellate courts and the first level throughout Indonesia. In an effort to improve the services of the judiciary to the community, it is necessary to evaluate the existing APM program. The evaluation is intended to find out whether the standardized performance has been able to meet the expectations of the community as users of judicial services. This study has benefit to provide consideration to stakeholders in the general justice environment and at the Supreme Court of Indonesia in making policies to make improvements to several accreditation criterias that are a priority for the community. The method used is descriptive quantitative by using matrix analysis of Importance Performance Analysis (IPA). The IPA matrix suitable as evaluation tools for APM program, because it shows importance and performance level from each APM's criteria to assess public satisfaction. The IPA Matrix is obtained from the values which are indicators of the APM criteria and public satisfaction. The results obtained from the analysis are a comparison of the real performance matrix that the court has given to public satisfaction achieved. The evaluation result based on the matrix shows many indicators from each APM's criteria that being public priority need to be improved by stakeholders. The criterias have been assessed public satisfaction are costumer focus and sources management. Meanwhile, the other criteria which not assess public satisfaction yet is process management.
\end{abstract}

Keyword: accreditation, courts, IPA, service quality 


\section{PENDAHULUAN}

Mahkamah Agung RI sebagai lembaga yang menaungi empat lingkungan peradilan di Indonesia, telah mengeluarkan SK Nomor: 026/KMA/SK/II/2012 tentang Standar Pelayanan Peradilan untuk menjalankan pelayanan publik sebagaimana dimaksud dalam UU Nomor 25 Tahun 2009. Surat Keputusan tersebut menyebutkan bahwa pengadilan harus dapat membangun kepercayaan masyarakat dengan meningkatkan kualitas pelayanan kepada publik. Pengadilan sebagai salah satu lembaga publik yang dalam kegiatannya memiliki tanggung jawab untuk memberikan pelayanan yang baik kepada seluruh lapisan masyarakat.

Pelayanan publik yang diberikan oleh pengadilan mengacu pada Undang-Undang Nomor 25 Tahun 2009 tentang pelayanan Publik. Undang-undang tersebut menjelaskan bahwa dalam melaksanakan pelayanan publik, beberapa hal yang harus diperhatikan adalah dalam penyelenggaraan pelayanan publik harus sesuai dengan asas-asas umum pemerintahan dan korporasi yang baik. Penyelenggaraan layanan pengadilan diharapkan dapat terlaksana secara jujur, adil, terbuka dan terpercaya serta jauh dari praktik korupsi, kolusi dan nepotisme. Dalam rangka meningkatkan kualitas layanan kepada masyarakat dan menjalankan SK Nomor: 026/KMA/SK/II/2012, Badan Peradilan Umum sebagai salah satu satuan kerja Mahkamah Agung RI yang membawahi lembaga peradilan umum mengeluarkan kebijakan tentang program Akreditasi Penjaminan Mutu (APM).

Program Akreditasi Penjaminan Mutu (APM) diselenggarakan dengan dasar hukum Keputusan Direktur Jenderal Badan Peradilan Umum Nomor: 1385a/DJU/SK/OT.01.3/09/2016 tentang Perubahan Tim Akreditasi Penjaminan Mutu Badan Peradilan Umum dan Keputusan Direktur Jenderal Badan Peradilan Umum Nomor: 2235/DJU/SK/OT.01.3/12/2017 tentang Pembentukan Tim Penyusunan Buku Pedoman Praktis Akreditasi Penjaminan Mutu Badan Peradilan Umum. Selama empat tahun berjalannya program APM ini hingga tahun 2018, diperoleh capaian yang sangat baik yaitu, 30 pengadilan tinggi dan 294 pengadilan negeri telah terakreditasi (Pedoman Praktis Pemeliharaan Akreditasi Penjaminan Mutu Badan Peradilan Umum, 2018). Pada umumnya, kategori akreditasi yang diperoleh pengadilan tinggi maupun pengadilan negeri adalah A atau $B$. Hal ini menunjukkan bahwa pengadilan telah berupaya melakukan peningkatan kualitas pemberian layanan hukum kepada masyarakat pencari keadilan.
Program Akreditasi Penjaminan Mutu (APM) yang dilaksanakan oleh Badan Peradilan Umum ini memiliki perbedaan dengan sistem manajemen mutu yang umum digunakan yaitu ISO 9001. Beberapa perbedaan tersebut dapat dilihat pada tabel 1 di bawah ini.

\begin{tabular}{|c|c|c|c|}
\hline No & Perbedaan & APM & ISO 9001 \\
\hline 1 & Tujuan & $\begin{array}{l}\text { Mewujudkan } \\
\text { kinerja } \\
\text { peradilan } \\
\text { yang unggul }\end{array}$ & $\begin{array}{l}\text { Mengelola } \\
\text { manajemen } \\
\text { organisasi } \\
\text { untuk } \\
\text { memenuhi } \\
\text { harapan } \\
\text { pelanggan }\end{array}$ \\
\hline 2 & Acuan & $\begin{array}{l}7 \text { area court } \\
\text { excellent } \\
\text { dan } 8 \text { area } \\
\text { reformasi } \\
\text { birokrasi }\end{array}$ & $\begin{array}{l}\text { Standar sistem } \\
\text { manajemen } \\
\text { mutu yang } \\
\text { diterbitkan oleh } \\
\text { ISO } \\
\text { (International } \\
\text { Organization for } \\
\text { Standarization) }\end{array}$ \\
\hline 3 & $\begin{array}{l}\text { Penyeleng } \\
\text { gara }\end{array}$ & $\begin{array}{l}\text { Badan } \\
\text { Peradilan } \\
\text { Umum MA } \\
\text { RI } \\
\end{array}$ & $\begin{array}{l}\text { ISO } \\
\text { (International } \\
\text { Organization for } \\
\text { Standarization) }\end{array}$ \\
\hline
\end{tabular}

Dari tabel 1 di atas dapat dilihat bahwa terdapat perbedaan yang mendasar antara program APM dengan ISO 9001. Hal ini karena, pada ISO 9001 memiliki kriteria yang bersifat umum untuk manajemen mutu suatu organisasi, sedangkan APM memiliki kriteria dan tujuan yang lebih khusus sebagaimana disesuaikan dengan visi Mahkamah Agung untuk mewujudkan badan peradilan yang agung. Keunggulan lain program APM ini sebagai sistem pengendalian mutu pengadilan adalah mudah untuk dilakukan pengawasan dan pembinaan oleh pengadilan tinggi di setiap provinsi untuk menjaga kualitas akreditasi yang sudah diperoleh.

Tujuh kriteria APM mengadopsi dari International Framework for Court Excellent (IFCE) dan Reformasi Birokrasi (RB) Mahkamah Agung RI yang dapat dilihat pada tabel 2 di bawah ini.

Pada tabel 2 dapat dilihat bahwa kriteria APM lebih banyak mengacu pada IFCE dengan mempertimbangkan 8 area Reformasi Birokrasi di Mahkamah Agung RI. Program APM yang sudah berjalan selama empat tahun ini tentunya memerlukan suatu evaluasi, untuk melihat kepuasan masyarakat sebagai dampak dari diterapkannya standar akreditasi pengadilan. Salah satu metode yang dapat digunakan untuk menganalisa kepuasan masyarakat terhadap layanan yang telah diberikan oleh lembaga adalah dengan matriks Importance Performance Analysis (IPA) (Purnomo \& Riandadari, 2015). 
Metode IPA sesuai untuk digunakan sebagai alat evaluasi penerapan program APM karena dalam matriks IPA mampu menggambarkan tingkat kepentingan dan performa nyata dari kriteria APM yang telah diberikan pengadilan dalam memberikan layanannya kepada masyarakat.

\begin{tabular}{|c|c|c|c|}
\hline No & IFCE & RB & APM \\
\hline 1 & $\begin{array}{l}\text { Kepemimpinan } \\
\text { dan } \\
\text { Manajemen } \\
\text { Pengadilan }\end{array}$ & $\begin{array}{l}\text { Manajemen } \\
\text { Perubahan }\end{array}$ & Kepemimpinan \\
\hline 2 & $\begin{array}{l}\text { Perencanaan } \\
\text { dan Kebijakan } \\
\text { Pengadilan }\end{array}$ & $\begin{array}{l}\text { Penataan } \\
\text { Peraturan } \\
\text { Perundang- } \\
\text { undangan }\end{array}$ & $\begin{array}{l}\text { Perencanaan } \\
\text { strategis }\end{array}$ \\
\hline 3 & $\begin{array}{l}\text { Sumber Daya } \\
\text { di pengadilan }\end{array}$ & $\begin{array}{l}\text { Penataan dan } \\
\text { penguatan } \\
\text { organisasi }\end{array}$ & $\begin{array}{l}\text { Fokus } \\
\text { pelanggan }\end{array}$ \\
\hline 4 & $\begin{array}{l}\text { Proses } \\
\text { penyelenggara } \\
\text { an } \\
\text { persidangan }\end{array}$ & $\begin{array}{l}\text { Penataan tata } \\
\text { laksana }\end{array}$ & $\begin{array}{l}\text { Manajemen } \\
\text { proses }\end{array}$ \\
\hline 5 & $\begin{array}{l}\text { Kebutuhan } \\
\text { dan kepuasan } \\
\text { pengguna }\end{array}$ & $\begin{array}{l}\text { Penataan } \\
\text { sistem } \\
\text { manajemen } \\
\text { SDM }\end{array}$ & $\begin{array}{l}\text { Sistem } \\
\text { dokumen }\end{array}$ \\
\hline 6 & $\begin{array}{l}\text { Akses } \\
\text { pelayanan } \\
\text { yang } \\
\text { terjangkau }\end{array}$ & $\begin{array}{l}\text { Penguatan } \\
\text { akuntabilitas }\end{array}$ & $\begin{array}{l}\text { Manajemen } \\
\text { sumber daya }\end{array}$ \\
\hline 7 & $\begin{array}{l}\text { Keyakinan dan } \\
\text { kepercayaan } \\
\text { kepada } \\
\text { pengadilan }\end{array}$ & $\begin{array}{l}\text { Penguatan } \\
\text { pengawasan }\end{array}$ & Hasil kinerja \\
\hline 8 & & $\begin{array}{l}\text { Peningkatan } \\
\text { kualitas } \\
\text { pelayanan } \\
\text { publik }\end{array}$ & \\
\hline
\end{tabular}

Hasil penelitian terdahulu menyebutkan bahwa IPA menjadi alat evaluasi yang cukup kuat untuk mampu menggambarkan komponen apa saja yang telah berjalan dengan baik dan komponen apa saja yang memerlukan perbaikan (Wong, Hideki, \& George, 2011). Selain itu, matriks IPA dapat digunakan untuk membandingkan harapan yang diinginkan oleh masyarakat sebagai pengguna dengan kinerja dari lembaga yang memberi layanan jasa (Yulianti, 2017).

Dengan demikian, yang menjadi rumusan masalah dalam tulisan ini adalah bagaimana evaluasi dari penerapan program Akreditasi Penjaminan Mutu di pengadilan dengan matriks Importance Performance Analysis (IPA). Hal yang ingin dilihat adalah apakah akreditasi pengadilan yang pada umumnya sudah memperoleh nilai $A$ atau $B$, sejalan dengan harapan masyarakat pada setiap kriteria APM untuk memperoleh performa layanan pengadilan yang berkualitas. Manfaat yang diharapkan adalah hasil analisis dengan IPA tersebut dapat digunakan sebagai masukan terhadap stakeholder pengadilan untuk senantiasa memperbaiki dan meningkatkan pelayanan pengadilan dalam berbagai aspek untuk memberikan pelayan yang berkualitas kepada masyarakat pencari keadilan.

\section{TINJAUAN PUSTAKA}

\subsection{Kualitas Layanan Pengadilan}

Terdapat 3 hal penting terkait dengan kualitas layanan yaitu: 1) kualitas layanan lebih sulit untuk dievaluasi daripada kualitas barang; 2) hasil dari persepsi tentang kualitas layanan merupakan perbandingan dari harapan konsumen dengan kinerja layanan yang sebenarnya, dan 3) evaluasi tentang kualitas tidak semata-mata dibuat berdasarkan dampak dari layanan tetapi juga melibatkan evaluasi dari proses pemberian layanan (Parasuraman, Zeithaml, \& Berry, 1985). Dinyatakan pula bahwa terdapat 10 dimensi terkait dengan persepsi masyarakat terhadap kualitas layanan, yaitu: 1) akses; 2) komunikasi; 3) kompetensi; 4) keramahan; 5) kredibilitas; 6) keandalan; 7) daya tanggap; 8) keamanan; 9) bukti nyata; 10) pemahaman terhadap pengguna. Dimensi kualitas layanan tersebut kemudian berkembang dalam suatu sistem manajemen mutu. Sistem manajemen mutu yang sering digunakan oleh organisasi adalah ISO 9001: 2008 yang kemudian diganti dengan ISO: 9001:2015.

Prinsip manajemen mutu yang diterapkan pada ISO 9001:2015 ini meliputi: 1) fokus pelanggan; 2) kepemimpinan, 3) pelibatan orang; 4) pendekatan proses, 5) peningkatan, 6) keputusan yang dibuat berdasarkan bukti; 7) manajemen relasi (BSN, 2015). Standar ini menentukan persyaratan sistem manajemen mutu yang dapat dipakai oleh organisasi untuk sertifikasi yang difokuskan pada keefektifan manajemen mutu dalam memenuhi harapan pelanggan.

Pada lembaga peradilan, dalam hal ini pengadilan menerapkan sistem manajemen mutu yang merujuk pada International Framework for Court Excellent (IFCE). Pada IFCE terdapat 11 unsur pengukuran kinerja pengadilan yaitu: 1) kepuasan pengguna pengadilan; 2) biaya akses; 3) tingkat penyelesaian perkara; 4) pemrosesan kasus yang tepat waktu; 5) durasi waktu sebelum sidang perkara; 6) integritas dalam pengarsipan berkas pengadilan; 7) proporsi kasus yang tertunda; 8) kepastian jadwal sidang; 9) komitmen petugas; 10) pemenuhan perintah pengadilan; 11) biaya per perkara (Hall \& Keilitz, 2012).

Mahkamah Agung RI dalam bukunya Cetak Biru Pembaruan Peradilan 2010-2035 telah memuat berbagai perencanaan strategis yang 
dilakukan dengan pendekatan kerangka pengadilan yang unggul (The Framework for Courts Excellence) (Mahkamah Agung RI, 2010). Tujuan dari perencanaan strategis tersebut adalah untuk mendapatkan pengadilan yang mampu memberikan pelayanan keadilan yang sebaik-baiknya. Permasalahan yang umum dihadapi masyarakat sebagai pengguna layanan pengadilan di antaranya adalah: lamanya proses berperkara, kurangnya pemahaman pencari keadilan dan pengguna pengadilan mengenai prosedur, dokumen dan persyaratan yang diperlukan, serta minimnya kepercayaan masyarakat terhadap lembaga peradilan (Mahkamah Agung RI, 2010).

Tabel 3 Kriteria dan indikator APM Badilum.

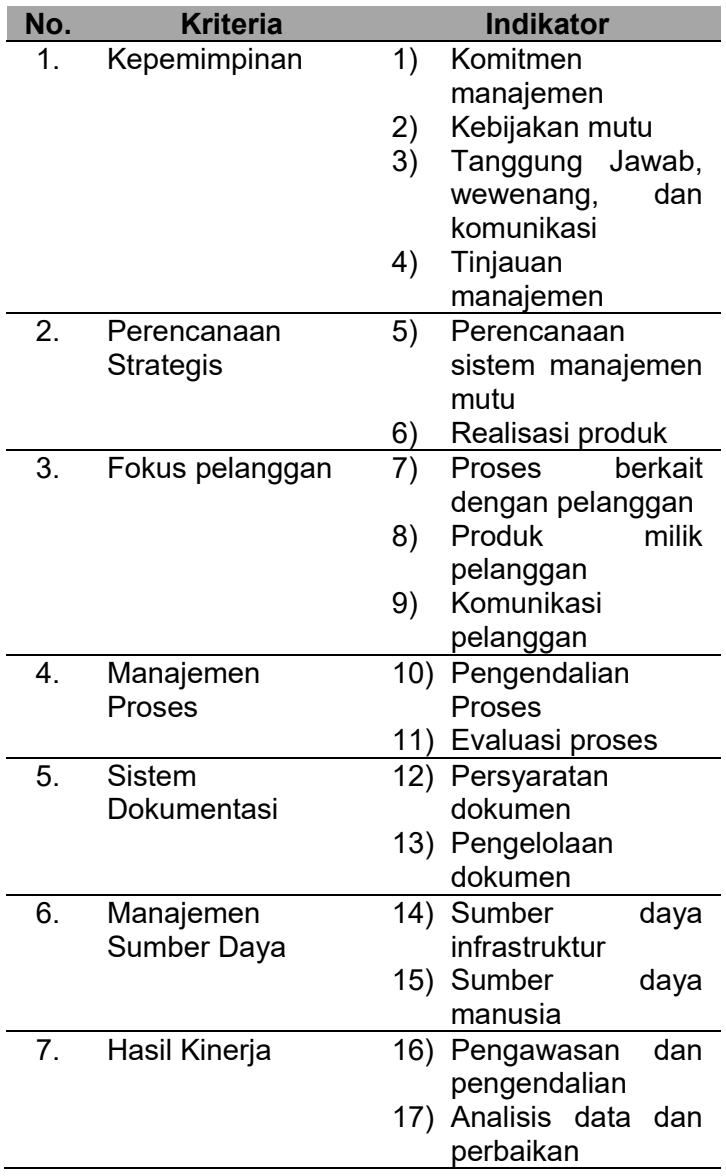

Menyikapi hal ini, salah satu satuan kerja di Mahkamah Agung RI yang membawahi peradilan umum yaitu Badan Peradilan Umum (Badilum) mengeluarkan kebijakan dengan membentuk Tim Akreditasi Penjaminan Mutu (APM) untuk menyusun kriteria penilaian kualitas layanan pengadilan. Kriteria APM tersebut disusun dengan mempertimbangkan pelaksanaan Reformasi Birokrasi, Pembangunan Zona Integritas dan standar pengawasan oleh Badan Pengawasan MA RI. Kemudian, dilaksanakan 118 pula pelatihan bagi tim APM dan hakim tinggi di seluruh Indonesia untuk dapat menjadi auditor/assesor di satuan kerja masing-masing (Maryana Joyosumarto, 2017).

Standar penilaian pengadilan dari Badilum tersebut dikenal dengan istilah Indonesia Court Performance Excellent (ICPE) yang memiliki 7 area yaitu: 1) kepemimpinan; 2) perencanaan strategis; 3) fokus pelanggan; 4) sistem dokumentasi; 5) manajemen sumber daya; 6) manajemen proses; 7) hasil kinerja. Pada tabel 3 berikut dirinci beberapa indikator dari masingmasing area yang menjadi standar penilaian akreditasi pengadilan yang digagas oleh Badilum.

\subsection{Kepuasan Masyarakat}

Kepuasan masyarakat merupakan hal yang paling krusial untuk mengukur keberhasilan suatu organisasi dan khususnya membawa dampak terhadap perilaku untuk menggunakan kembali dan mengkomunikasikan kualitas produk/layanan yang dimiliki oleh organisasi tersebut (Al-Ali, Bazin, \& Shamsuddin, 2015). Perasaan puas yang dicapai oleh masyarakat yang menggunakan suatu layanan/produk mengarah pada perilaku memuji dimana kepuasan tersebut menunjukkan adanya kesempatan bagi organisasi untuk semakin melangkah ke depan terhadap kualitas layanan/produk yang dimiliki (Johnston, 1995). Kepuasan masyarakat menjadi tugas penting oleh setiap manajemen lembaga yang harus dicapai karena menjadi ukuran kesuksesan suatu lembaga dalam menjalankan kegiatan organisasinya (Suzana \& Kijev, 2012).

Kepuasan masyarakat memiliki 3 bagian penting yaitu: kualitas yang dirasakan secara nyata, nilai nyata yang dirasakan, dan harapan masyarakat terhadap produk/layanan (Anderson \& Claes Fornell, 2000). Kualitas kinerja yang diberikan organisasi untuk memberikan pelayanan kepada masyarakat diharapkan dapat membawa dampak positif untuk kepuasan masyarakat. Kemudian nilai yang dirasakan masyarakat sebagai pengguna layanan barang/jasa merupakan tingkat kewajaran kualitas terhadap biaya yang dikeluarkan untuk memperolehnya. Selanjutnya adalah harapan masyarakat yang dapat menjadi pertimbangan organisasi untuk meningkatkan kualitas layanan barang/jasa yang ditawarkan (Anderson \& Claes Fornell, 2000).

Pengukuran kepuasan masyarakat tersebut dapat dilakukan dengan menghitung indeks yang diperoleh dari indikator-indikator kepuasan masyarakat yang disusun secara sistematis yang kemudian dikenal dengan singkatan IKM (Indeks Kepuasan Masyarakat) (Triyono \& Putera, 2013). Pengukuran IKM tersebut menjadi ukuran kualitas dari barang/jasa 


\begin{abstract}
yang digunakan oleh masyarakat. Bagi organisasi, IKM dapat menjadi alat evaluasi terhadap layanan barang/jasa yang diberikan kepada masyarakat. IKM mampu mengukur dengan baik seberapa besar kualitas layanan barang/jasa tersebut mampu memenuhi harapan masyarakat (Benjamin, 2012). Beberapa faktor yang mempengaruhi kepuasan masyarakat diantaranya adalah kualitas layanan, fasilitas dan harga yang harus dikeluarkan oleh masyarakat untuk mendapatkan layanan (Haryanto, 2013).
\end{abstract}

Harapan masyarakat terhadap layanan barang/jasa tersebut merupakan refleksi dari berbagai aspek aktivitas organisasi dalam prosesnya memberikan layanan terhadap masyarakat termasuk pula bagaimana kondisi lingkungan, fasilitas dan petugas yang terkait dengan saat pemberian layanan.Pengukuran kepuasan masyarakat menjadi penting untuk dilakukan karena sangat berkaitan dengan pertumbuhan dan berkembangnya suatu organisasi (Sonne, 1992).

Setelah dilakukan pengukuran IKM, maka perlu pula dilakukan analisis terhadap tingkat kinerja dan tingkat harapan masyarakat untuk memperoleh informasi sejauhmana organisasi mampu memberikan pelayanan yang efektif. Analisis tersebut dapat dilakukan dengan membuat matriks Importance Performance Analysis (IPA). Gambar 1 berikut menampilkan kuadran pada matriks IPA.

\begin{tabular}{c|c|c|}
\cline { 2 - 3 } Sangat Tinggi & $\begin{array}{c}\text { Kuadran II } \\
\text { "Konsentrasi } \\
\text { Disini" }\end{array}$ & $\begin{array}{c}\text { Kuadran I } \\
\text { "Pertahankan Kinerja } \\
\text { Dengan Baik" }\end{array}$ \\
\cline { 2 - 3 } HARAPAN & $\begin{array}{c}\text { Kuadran III } \\
\text { "Prioritas Rendah" }\end{array}$ \\
\hline & Kuadran IV \\
"Terlalu Berlebihan"
\end{tabular}

Sumber: (Martilla \& James, 1977)

Gambar 1 Matriks kuadran IPA.

Penjelasan makna kuadran pada gambar 1 tersebut adalah:

a. Kuadran I (Pertahankan kinerja dengan baik) artinya faktor-faktor yang dianggap penting bagi masyarakat dalam pemenuhan kepuasan mereka saat memperoleh layanan telah dipenuhi dengan baik oleh organisasi. Dengan demikian, organisasi harus menjaga dan mempertahankan kinerja faktor-faktor kepuasan pelanggan pada kuadran I.

b. Kuadran II (Konsentrasi disini) menunjukkan bahwa organisasi belum mampu memberikan kinerja secara maksimal terhadap faktorfaktor yang dianggap penting untuk memenuhi kepuasan masyarakat. Oleh karena itu, perlu dilakukan tindakan

perbaikan sebagai upaya untuk
meningkatkan inerja organisasi.

c. Kuadran III (Prioritas rendah) menunjukan organisasi masih memberikan kinerja yang rendah untuk faktor-faktor yang dianggap tidak terlalu penting untuk pemenuhan kepuasan masyarakat. Oleh sebab itu, perbaikan kinerja pada faktor-faktor di kuadran III bukan menjadi prioritas organisasi.

d. Kuadran IV (Terlalu berlebihan) menunjukkan bahwa organisasi telah memberikan kinerja yang baik untuk faktor-faktor yang dianggap tidak terlalu penting untuk pemenuhan kepuasan terhadap masyarakat. Dengan demikian, organisasi perlu meninjau kembali untuk mengalihkan sumber daya yang dgunakan pada kuadran IV untuk dimanfaatkan pada faktor lain yang dianggap lebih penting untuk pemenuhan kepuasan masyarakat.

Penelitian sebelumnya yang dilakukan oleh (Wong et al., 2011) menyatakan bahwa IPA merupakan alat strategis yang dapat memberikan hasil secara cepat untuk mengetahui apa yang masyarakat butuhkan dan inginkan untuk mencapai kepuasan pelanggan. Hasil penelitian tersebut menemukan faktor-faktor apa saja yang perlu untuk diperbaiki dan ditingkatkan untuk memenuhi kepuasan masyarakat dengan berdasarkan perspektif stakeholder. Matriks IPA tersebut sangat membantu stakeholder dalam menentukan langkah dalam menyusun perencanaan strategis lembaga. Kemudian artikel ini pun memiliki tema yang sama dalam menerapkan IPA dalam lembaga. Perbedaannya adalah dalam artikel ini matriks IPA disusun berdasarkan perspektif masyarakat sebagai pengguna layanan. Perspektif masyarakat dipilih untuk menentukan matriks IPA agar dapat dianalisis apakah model kebijakan yang dibuat oleh stakeholder sudah sejalan dengan apa yang diinginkan dan dibutuhkan oleh masyarakat. Hal ini dikarenakan pengembangan model layanan kepada masyarakat dengan memprioritaskan pada pencapaian kepuasan masyarakat merupakan cara yang efektif untuk meningkatkan kualitas layanan (Alizadeh, Kianfar, Alizadeh, \& Kianfar, 2013).

\section{METODE PENELITIAN}

Metode penelitian yang digunakan adalah penelitian deskriptif kuantitatif dengan teknik pengambilan sampel accidental sampling. Accidental sampling yaitu pemilihan sampel dilakukan terhadap seseorang yang secara kebetulan dijumpai. Maksudnya adalah sampel yang dipilih merupakan masyarakat yang ada saat dilaksanakan penyebaran kuesioner. Teknik 
sampling ini dipilih dengan pertimbangan untuk memperoleh sampel secara acak saat tim penelitian turun ke lapangan melakukan pengambilan data.

Rentang waktu pengambilan data dilakukan pada bulan April 2018. Jenis data yang diperoleh merupakan data primer yang diperoleh langsung dari masyarakat sebagai responden. Masyarakat yang menjadi responden merupakan masyarakat yang sedang melakukan proses layanan hukum di pengadilan, baik masyarakat awam maupun polisi dan jaksa yang sedang berkepentingan di pengadilan. Tempat pengambilan data dilakukan di peradilan umum tingkat pertama di wilayah hukum Jawa Tengah, Jawa Timur dan Sulawesi Selatan. Adapun untuk wilayah hukum Jawa Tengah meliputi: Pengadilan Negeri Semarang, Pengadilan Negeri Demak, Pengadilan Negeri Kudus, Pengadilan Negeri Pati dan Pengadilan Negeri Rembang. Kemudian untuk wilayah hukum Jawa Timur meliputi: Pengadilan Negeri Malang, Pengadilan Negeri Kepanjen dan Pengadilan Negeri Mojokerto. Selanjutnya, untuk wilayah hukum Sulawesi Selatan meliputi: Pengadillan Negeri Makassar, Pengadilan Negeri Sungguminasa, Pengadilan Negeri Maros dan Pengadilan Negeri Pangkajene. Proses membagikan kuesioner dilakukan secara acak kepada siapa saja yang sedang berkepentingan di pengadilan saat menjalani proses layanan hukum.

Kemudian instrumen penelitian yang digunakan berupa kuesioner tertutup dengan penilaian skala likert (1-5). Kuesioner tersebut berisi pernyataan tentang beberapa indikator dari kriteria APM yang telah disebutkan dalam tabel 3. Kemudian dibandingkan antara skor kualitas nyata layanan pengadilan yang diterima masyarakat dengan kualitas harapan dari masyarakat terhadap layanan pengadilan tersebut. Kuesioner tersebut kemudian dianalisis dengan matriks Importance Performance Analysis (IPA) untuk melihat sejauh mana kualitas layanan pengadilan saat ini. Rincian indikator yang digunakan dalam kuesioner telah disampaikan sebagaimana dalam tabel 3 di atas dengan merujuk dari Buku "Akreditasi Menuju Peradilan Modern" yang disusun oleh Direktorat Jenderal Badan Peradilan Umum.

Responden penelitian ini berjumlah 124 orang yang merupakan masyarakat pencari keadilan yang memiliki beragam profesi dan berasal dari tiga wilayah hukum. Pada masingmasing wilayah diambil kurang lebih 41 responden yang tersebar dalam beberapa peradilan umum tingkat pertama yang mewakili. Skor hasil kuesioner tersebut ditabulasi kemudian dihitung nilai rata-rata untuk masing-masing indikator. Setelah itu, dilanjutkan pembuatan matriks IPA dengan aplikasi SPSS versi 23.
Tahapan dalam membuat matriks IPA berdasarkan data kuesioner dengan menggunakan aplikasi SPSS adalah sebagai berikut:

a. Menghitung rata-rata skor penilaian kinerja pengadilan $(\bar{X})$

b. Menghitung rata-rata skor penilaian kepuasan masyarakat pengguna layanan $(\bar{Y})$

c. Membuat matrik IPA dengan menggunakan menu Graphs pada SPSS dengan memilih model grafik Scatter/Dot

d. Menginput varibel $X$ dan $Y$ yang menjadi koordinat kemudian pilih OK hingga muncul grafik IPA yang diinginkan

e. Memunculkan garis tengah pada sumbu $X$ dan $Y$ melalui menu chart editor dan mengisi $X$ dan $Y$ axis reference line set to: mean

f. Setelah muncul garis tengah pada sumbu $X$ dan $Y$, dilanjutkan dengan menganalisisnya sesuai makna keempat kuadran pada matriks IPA

\section{HASIL DAN PEMBAHASAN}

Program APM sudah dilaksanakan sejak tahun 2015 hingga saat ini untuk pengadilan tinggi dan pengadilan negeri di seluruh Indonesia. Hasil yang sudah dicapai APM saat ini adalah telah terakreditasinya 30 pengadilan tinggi dan 294 pengadilan negeri dengan nilai perolehan akreditasi antara A/B. Hal ini merupakan pencapaian yang luar biasa karena dalam kurun waktu 3 tahun hampir seluruh pengadilan negeri telah terakreditasi (294 dari 352 pengadilan negeri), bahkan untuk pengadilan tinggi semuanya telah terakreditasi (30 pengadilan tinggi) (Pedoman Praktis Pemeliharaan Akreditasi Penjaminan Mutu Badan Peradilan Umum, 2018).

Akan tetapi, pencapaian tersebut tidak membuat pengadilan yang telah terakreditasi berpuas diri begitu saja. Pengadilan masih harus senantiasa berusaha untuk mempertahankan dan meningkatkan kualitas layanan yang diberikan kepada masyarakat. Kualitas layanan pengadilan yang diwakili dalam 7 kriteria APM. Oleh sebab itu, perlu dilakukan evaluasi terhadap 7 kriteria APM tersebut untuk melihat tingkat kualitas layanan yang diberikan oleh pengadilan kepada masyarakat melalui matriks Importance Performance Analysis (IPA). Matriks IPA digunakan untuk membandingkan antara harapan yang diinginkan masyarakat pengguna layanan pengadilan dengan kinerja nyata dari pihak petugas di pengadilan (Yulianti, 2017). Gambar 2 di bawah ini merupakan matriks IPA dari 7 kriteria 
APM yang telah diturunkan dalam 17 indikator

yang telah disebutkan dalam tabel 3 .

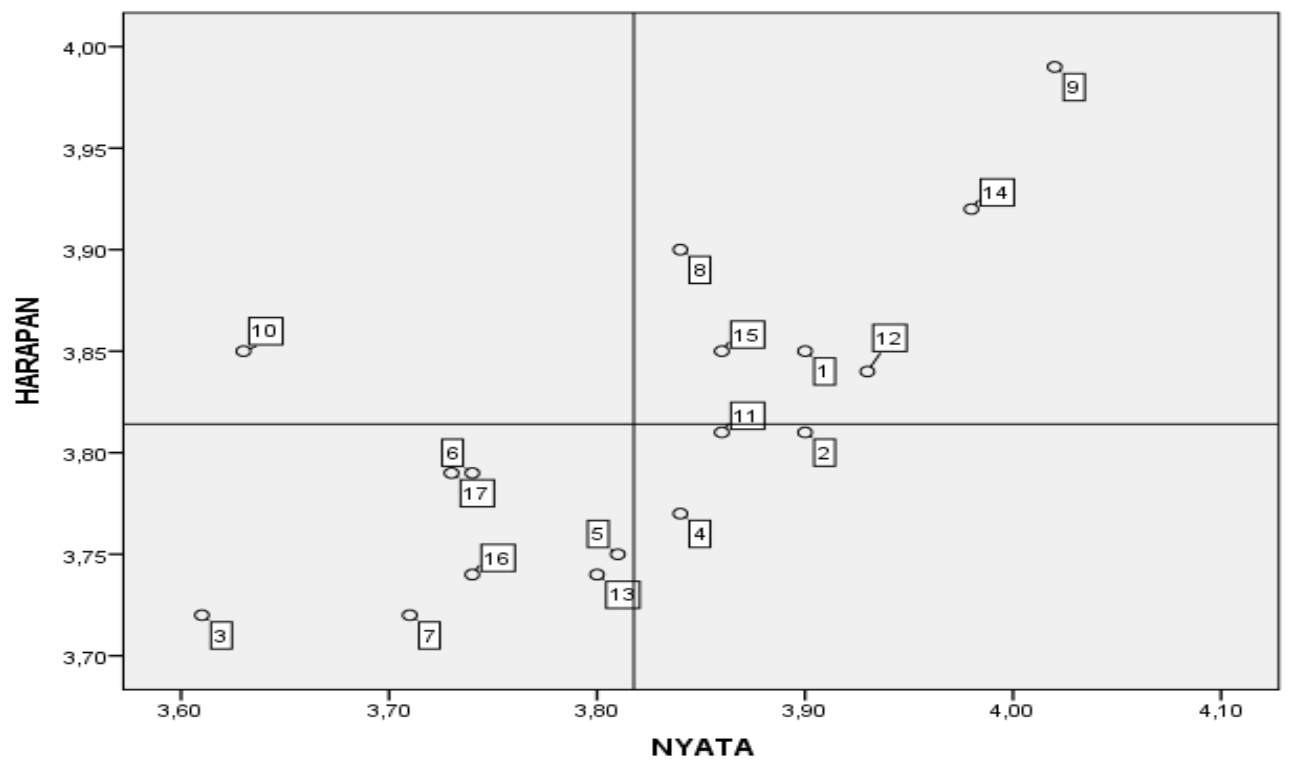

Sumber: data diolah (2018).

Gambar 2 Matriks IPA.

Matriks IPA tersebut dibuat dengan membandingkan nilai rata-rata dari tiap indikator APM yang dinilai sesuai apa yang nyata dirasakan dengan apa yang diharapkan masyarakat sebagai pengguna layanan pengadilan. Gambar 2 di atas terbagi dalam empat kuadran sebagaimana mengacu pada gambar 1 yang masing-masing kuadran dapat diinterpretasikan sebagai berikut:

a. Indikator kualitas layanan pengadilan yang berada di kuadran I yaitu keep up the good work (terus kerjakan dengan baik) antara lain:

1) Pengembangan kapasitas pribadi (indikator No. 1, kriteria kepemimpinan)

2) Biaya dan tarif (indikator No. 8, kriteria fokus pelanggan)

3) Kompetensi pelaksana (indikator No. 9, kriteria fokus pelanggan)

4) Dokumen Standar Operational Procedure (indikator No. 12, kriteria sistem dokumentasi)

5) Sumber daya manusia (indikator No. 14, kriteria manajemen sumber daya)

6) Sumber daya infrastruktur (indikator No. 15 , kriteria manajemen sumber daya)

Pada kuadran ini, 6 indikator tersebut dianggap sangat penting dan kinerjanya telah dipenuhi dengan baik oleh pengelola layanan. Implikasinya adalah, pengelola pengadilan harus menjaga dan mempertahankan kinerja indikator tersebut sebagai upaya perbaikan kualitas pelayanan dan peningkatan kepuasan masyarakat. b. Pada kuadran II yaitu concentrate here (konsentrasi di sini) hanya ada satu indikator kualitas layanan pengadilan yaitu tanggung jawab manajemen (indikator No. 10, kriteria manajemen proses). Hal ini dapat diartikan indikator tersebut dianggap sangat penting oleh masyarakat tetapi kinerjanya belum mampu dipenuhi oleh pengelola pelayanan pengadilan. Dengan demikian, pihak pengadilan harus memprioritaskan tindakan perbaikan pada indikator tersebut. Hal ini disebabkan kinerja dari pengadilan belum mencapai level yang diharapkan masyarakat. Tindakan perbaikan yang dapat dilakukan oleh pengadilan adalah dengan menyusun kebijakan yang mengatur dengan jelas bentuk tanggung jawab dari pengadilan terhadap masyarakat apabila tidak memberikan pelayanan sebagaimana standar prosedur pelayanan yang ada.

c. Terdapat 7 indikator pada kuadran III yaitu low priority (prioritas rendah) antara lain:

1) Pandangan tentang masa depan (indikator No. 3, kriteria kepemimpinan)

2) Kebijakan mutu (indikator No. 5, kriteria perencanaan strategis)

3) Sasaran mutu (indikator No. 6, kriteria perencanaan strategis)

4) Jangka waktu (indikator No. 7, kriteria fokus pelanggan)

5) Formulir Akreditasi (indikator No.13, kriteria sistem dokumentasi)

6) Pengawasan dan pengukuran (indikator No. 16 , kriteria hasil kinerja) 
7) Assesmen internal (indikator No. 17, kriteria hasil kinerja).

Indikator di atas dianggap kurang penting dan kinerja yang diberikan oleh pengelola pengadilan juga masih rendah. Implikasinya adalah perbaikan kinerja pada indikator tersebut bukan menjadi prioritas pada pelayanan pengadilan.

d. Terdapat 3 indikator kualitas pelayanan pengadilan yang berada di kuadran IV yaitu possible overkill (terlalu berlebihan) antara lain:

1) Membangun paradigma dan sikap mental (indikator No. 2, kriteria kepemimpinan)

2) Berpikir sistematis (indikator No. 4, kriteria kepemimpinan)

3) Analisis pengukuran (indikator No. 11, kriteria manajemen proses)

Pada kuadran ini, empat indikator tersebut dianggap belum terlalu penting bagi masyarakat, tetapi kinerja yang diberikan oleh pengadilan sudah baik. Dengan demikian, sumber daya yang digunakan untuk pencapaian kinerja pada indikator kualitas tersebut seharusnya dapat dialihkan pada indikator kualitas lain yang lebih penting.

Berdasarkan hasil dari analisis matriks IPA pada gambar 2 di atas, hal yang penting untuk diperhatikan oleh stakeholder pengadilan untuk meningkatkan kualitas layanannya adalah dalam manajemen proses khususnya dalam hal tanggung jawab manajemen. Tanggung jawab manajemen merupakan kewajiban pengadilan untuk menjalankan tugas dengan baik dalam memberikan pelayanan sebaik mungkin kepada masyarakat. Pelayanan pengadilan yang baik dapat terwujud apabila setiap petugas pengadilan mampu melaksanakan fungsinya sesuai dengan arahan pimpinan dan kemampuan yang dimiliki.

Analisis matriks IPA juga menunjukkan bahwa pengadilan telah memberikan kualitas pelayanan yang sesuai dengan harapan masyarakat dalam hal fokus pelanggan, prosedur pelayanan dan manajemen sumber daya. Kriteria tersebut harus dipertahankan oleh pengadilan untuk menjaga manajemen mutu layanannya dan akan lebih baik apabila dapat ditingkatkan. Peningkatan kualitas layanan pengadilan dapat diwujudkan dengan membangun ide-ide yang inovatif untuk senantiasa menyesuaikan dengan perkembangan kebutuhan masyarakat sebagai pengguna layanan pengadilan. Inovasi yang dilakukan bisa dalam bentuk penetapan dan penerapan program yang merupakan bagian dari strategi lembaga dalam meningkatkan kepercayaan masyarakat terhadap kinerja lembaga untuk mendorong terwujudnya kepuasan masyarakat (Anggraeny, 2013).
Matriks IPA sebagai alat evaluasi bagi pengadilan sangat berguna untuk menemukan proses layanan apa saja yang sudah berjalan dengan baik, yang perlu ditingkatkan dan bagian mana yang memerlukan tindak lanjut segera serta sangat membantu untuk menentukan fokus area-area strategis untuk kemajuan pengadilan di masa depan (Wong et al., 2011). Pengadilanpengadilan yang telah mendapat sertifikat APM juga telah menerapkan beberapa inovasi yang dipandang perlu untuk meningkatkan pelayanan kepada masyarakat. Inovasi yang mulai diterapkan di antaranya adalah: Auto Text Recording (ATR) yang merupakan sistem pencatatan secara otomatis saat jalannya persidangan, E-Skum (sistem perhitungan mandiri panjar biaya perkara), Pelayanan Terpadu Satu Pintu (PTSP), pengembangan aplikasi administrasi perkantoran berbasis android dan masih banyak lainnya.

Inovasi-inovasi tersebut tentunya tidak mudah diterapkan, karena untuk bisa menjalankan inovasi tersebut yang sebagian besar berbasis elektronik memerlukan petugas yang paham akan IT serta perlu ketersediaan anggaran untuk pemeliharaannya. Saat ini, lembaga pemerintah memang harus mulai terbiasa dengan peralihan era manual ke era digital karena banyaknya perkembangan aplikasiaplikasi berbasis data untuk memudahkan pekerjaan sehari-hari. Perkembangan dunia teknologi membuat batas ruang dan waktu menjadi tidak tampak, sehingga untuk menjadi lembaga yang maju di zaman sekarang ini dan mampu memenuhi kebutuhan masyarakat pencari keadilan, pengadilan harus mau beranjak dan berinovasi menerapkan sistem-sistem berbasis digital untuk meningkatkan mutu layanannya kepada masyarakat. Bagi pengadilan sebagai sektor publik inovasi merupakan tuntutan akuntabilitas, transparansi dan implementasi dari good governance untuk mewujudkan organisasi publik yang berkinerja unggul (Hilda, 2014).

Hasil analisis dari matriks IPA terhadap indikator pada kriteria Akreditasi Penjaminan Mutu pengadilan dapat dijelaskan sebagai berikut:

a. Kepemimpinan

Indikator komitmen manajemen telah mampu dipenuhi dengan baik oleh pengadilan, sehingga apa yang diharapkan masyarakat akan komitmen lembaga dalam memberikan layanan yang semakin baik dapat tercapai. Beberapa indikator lainnya seperti kebijakan mutu, tanggung Jawab, wewenang, dan komunikasi tinjauan manajemen masih memerlukan perhatian untuk dilakukan perbaikan sebagaimana prioritas pada matriks IPA. 
b. Perencanaan Strategis

Dua indikator pada kriteria perencanaan strategis ada pada kuadran prioritas rendah dan belum memenuhi harapan masyarakat. Dengan demikian stakeholder pengadilan perlu meninjau kembali kebijakan terkait akan perencanaan strategis ini.

\section{c. Fokus Pelanggan}

Terdapat dua indikator pada fokus pelanggan yang sudah dapat dipenuhi dengan baik oleh pengadilan dalam memberikan layanan yang berkualitas kepada masyarakat. Oleh sebab itu, pengadilan harus menjaga kinerja dari pemberian produk layanan dan komunikasi kepada masyarakat untuk tetap dapat memenuhi harapan masyarakat.

\section{d. Manajemen Proses}

Pada indikator ini memerlukan perhatian khusus dari pengadilan karena merupakan faktor yang menjadi prioritas bagi masyarakat pengguna tetapi pengadilan belum mampu memberikan layanan optimal yang diharapkan. Pengadilan harus mampu mempertimbangkan kembali faktor apa yang menjadi prioritas, sehingga tidak terjadi kesalahan dalam penentuan prioritas.

\section{e. Sistem Dokumentasi}

Indikator pada sistem dokumentasi telah menunjukkan hasil kinerja yang baik dan memenuhi harapan masyarakat pengguna. Meskipun ada satu indikator lain yang ada pada prioritas rendah dan pengadilan pun belum mampu memberikan kinerja yang baik terhadap masyarakat.

\section{f. Manajemen Sumber Daya}

Indikator sumber daya manusia dan infrastruktur pengadilan telah mampu memberikan hasil kinerja yang baik dalam usaha mencapai kepuasan masyarakat pengguna layanan pengadilan.

\section{g. Hasil Kinerja}

Indikator pengawasan dan penilaian internal dari pengadilan menjadi prioritas yang rendah bagi masyarakat. Dengan demikian, pengadilan perlu mengkaji kembali hal-hal apa saja yang menjadi kebutuhan masyarakat dalam upaya untuk mendapatkan layanan keadilan yang berkualitas

\section{KESIMPULAN}

Berdasarkan paparan di atas dapat disimpulkan bahwa program Akreditasi Penjaminan Mutu Pengadilan telah mampu memenuhi kebutuhan masyarakat pencari keadilan khususnya pada kriteria fokus pelanggan dan manajemen sumber daya. Meskipun, untuk lima kriteria lainnya yaitu: kepemimpinan, perencanaan strategis, manajemen proses, sistem dokumentasi dan hasil kinerja masih memerlukan perhatian untuk diperbaiki. Dengan demikian, para pembuat kebijakan perlu mempertimbangkan aspirasi dari masyarakat tentang faktor apa saja yang perlu diperbaiki dan ditingkatkan dalam layanan pengadilan. Hal tersebut dapat dilakukan dengan menindaklanjuti dan membangun komunikasi aktif dengan masyarakat untuk menyampaikan kritik sarannya. Hal ini diharapkan dapat mewujudkan layanan pengadilan yang sesuai dengan harapan masyarakat.

\section{UCAPAN TERIMA KASIH}

Ucapan terima kasih kami sampaikan kepada para Ketua Pengadilan Tinggi, hakim tinggi dan hakim tingkat pertama lingkungan peradilan umum beserta segenap masyarakat yang ada di wilayah Jawa tengah, Jawa Timur, dan Sulawesi Selatan. Serta kepada Pusat Penelitian dan Pengembangan Hukum dan Peradilan Mahkamah Agung RI

\section{DAFTAR PUSTAKA}

Akreditasi Menuju Peradilan Modern. (2018). Jakarta: Direktorat Jenderal Badan Peradilan Umum.

Al-Ali, M., Bazin, N. E. N., \& Shamsuddin, S. M. (2015). Key Determinants of Customer Satisfaction: Evidence From Malaysia Grocery Stores. Journal Theoretical and Applied Information Technology, 74(3), 286299.

Alizadeh, A., Kianfar, F., Alizadeh, A., \& Kianfar, F. (2013). Developing a Model for Citizens' Satisfaction With Public Sector Services Based on Rough Sets Theory: a Case Study of Tehran Municipality. Technical Gazette, 20(5), 795-805.

Anderson, E. W., \& Claes Fornell. (2000). The Customer Satisfaction Index as a Leading Indicator. In Teresa A. Swartz \& D. lacobucci (Eds.), Handbook of Services Marketing and Management (pp. 255-267). California, USA: Sage Publication.

Anggraeny, C. (2013). Inovasi Pelayanan Kesehatan dalam Meningkatkan Kualitas Pelayanan di Puskesmas Jagir Kota Surabaya. Jurnal Kebijakan Dan Manajemen Publik, I(1), 85-93.

Benjamin, A. J. (2012). Service Quality and Customer Satisfaction in Public Sector Organizations: a Case Study of the Commission on Human Rights and Administrative Justice. Institute of Distance Learning, Kwame Nkrumah University of Science and Technology.

BSN. (2015). Quality management systems - 
Requirements Sistem manajemen mutu Persyaratan. Jakarta: BSN.

Direktorat Jenderal Badan Peradilan Umum. (2018). Pedoman Praktis Pemeliharaan Akreditasi Penjaminan Mutu Badan Peradilan Umum. Jakarta.

Hall, D. H., \& Keilitz, I. (2012). Global Measures of Court Performance. Retrieved from http://www.courtexcellence.com/ /media/Mi crosites/Files/ICCE/Global Measures_V3_11_2012.ashx

Haryanto, E. (2013). Kualitas Layanan, Fasilitas dan Harga Pengaruhnya Terhadap Kepuasan Pengguna Jasa Layanan Pada KAntor Samsat Manado. Jurnal Ekonomi, Manajemen, Bisnis Dan Akuntansi, 1(3), 750-760.

Hilda, N. (2014). Strategi Inovasi Layanan dalam Meningkatkan Kualitas Pelayanan di Kantor Pertanahan Kota Surabaya II. Jurnal Kebijakan \& Administrasi Publik, 2(1), 1-10.

Johnston, R. (1995). The Determinants of Service Quality: Satisfiers and Dissatisfiers. International Journal of Service Industry Management, 6(5), 53-71. https://doi.org/10.1108/09564239510101536

Mahkamah Agung RI. (2010). Cetak biru pembaruan peradilan 2010-2035. Jakarta: Mahkamah Agung RI.

Martilla, J. A., \& James, J. C. (1977). ImportancePerformance Analysis. Journal of Marketing, 41(1), 77-79. https://doi.org/10.2307/1250495

Maryana Joyosumarto. (2017). Tren Akreditasi Badilum. Dandapala: Penjaga Keadilan, III, 58-61.

Parasuraman, A., Zeithaml, V. A., \& Berry, L. L.
(1985). Model Service Its Quality and Implications for Future. The Journal of Marketing, 49(4), 41-50.

Purnomo, W., \& Riandadari, D. (2015). Analisa Kepuasan Pelanggan Terhadap Bengkel Dengan Metode IPA (Importance Performance Analysis) di PT. Arina Parama Jaya Gresik. Jurnal Teknik Mesin, 03(03), 54-63.

Sonne, A. (1992). Determinants of Customer Satisfaction with Professional Services - A Study of Consultant Services. Ekonomisk Fiskeriforskning, 9(2), 97-106.

Suzana, Đ., \& Kijev, V. (2012). Service Quality As Determinant of Customer Satisfaction. Economics and Organization, 9(179066), 311-325.

Triyono, B., \& Putera, P. B. (2013). Indeks Kepuasan Masyarakat Spesifik Lembaga Penelitian Dan Pengembangan: Implementasi Model ACSI. Jurnal Borneo Administrator, 9(1), 53-74.

Wong, M. S., Hideki, N., \& George, P. (2011). The Use of Importance-Performance Analysis (IPA) in Evaluating Japan's Egovernment Services. Journal of Theoretical and Applied Electronic Commerce Research, 6(2), 17-30. https://doi.org/10.1109/ICSSSM.2012.62523 20

Yulianti, Y. (2017). Analisis Kualitas Pelayanan Pendidikan Dengan Menggunakan Gap Analysis Dan Importance Performance Analysis (IPA) Pada Program Studi Pendidikan Ekonomi Fakultas Ekonomi UNY. Jurnal Pendidikan Ekonomi, 6(2), 122-133. 